\title{
Jerusalem in the Ottoman Rule (1516-1917 AD)
}

\author{
Dr Zakaria Ibrahim Al-Sinwar* \\ Professor of Modern and Contemporary History, the Islamic University of Gaza
}

*Corresponding Author: Dr Zakaria Ibrahim Al-Sinwar, Professor of Modern and Contemporary History, the Islamic University of Gaza

\begin{abstract}
Jerusalem enjoyed a special status during the period of Islamic rule, because of its religious status in Islam, it was ruled by the Ottomans 400 years (1516-1917), It passed through three stages, the foreign ambitions of Europe and Zionism emerged.

This study deals with the situation of Jerusalem under the Ottoman rule in its first era and then its conditions under Egyptian rule and then in the late Ottoman period until 1917 as you study European ambitions in the city and excavations and excavations in Jerusalem, Jerusalem in the late Ottoman era and the goals of those excavations and then dealt with the Zionist settlement in Jerusalem and how it was beginning individual efforts by taking a dimension of "charity" in favour of the poor Jews and then became a settlement directed by the Zionist movement and the extent of settlement.
\end{abstract}

Keywords: Jerusalem, Ottoman Rule, Egyptian Rule in Palestine, European Ambitions, Zionist Settlement

\section{INTRODUCTION}

The city of Jerusalem has a special religious status. It is the first Muslim qibla to Muslims in their prayers before the Kaaba in Makkah, and to Prophet's isra to and mi'raj at night from Mecca and after his arrival prayed at $\mathrm{Al}$ Aqsa Mosque. It is one of the three most important mosques in the world after the Holy Mosque in Mecca and the Prophet's Mosque in Madinah, so the Muslim caliphs were keen to open Jerusalem and make it under Islamic rule. They saw that its continued existence under Islamic rule is a religious duty. Jerusalem, and received the keys to the city of the Patriarch of Jerusalem, Safarine and gave the Christians a security document Known as the age-old guardianship, which gave them safety over their lives and their families, their money, their churches, and gave them freedom of belief.

The rule of Jerusalem revolve, the caliphs' adults, then the Umayyad state, then the Abbasid state, and the stage of weakness occupied by the Crusaders in 1099, and remained under occupation suffering from torture and persecution 98 years, when recovered by Saladin after the Battle of Hittin and remained under the rule of the Ayyubids after him until he took over the reins of Mamluk rule, it remained under the rule of the Mamluks until the Turkish Ottomans arrived in 1516.

This study deals with the conditions of Jerusalem under the Ottoman rule in its various phases, the European ambitions in this holy city of special importance, as well as the Zionist ambitions in it, and the Zionist settlement in Jerusalem at the end of the Ottoman rule.

The Ottomans defeated the Mamluks in the battle of Marj Dabak, near Aleppo, on 22/23 (August) 1516, did not find the Ottomans Mamluk resistance in the Levant after their victory in Marj Dabak, The Mamluk forces stationed in the Levant withdrew to Egypt, facing their final defeat in the Battle of Raidaniyah in $1517 \mathrm{AD}$, and the Shami cities announced the acceptance of the Ottoman rule. After Marj Dabak, Sultan Selim moved his army to Damascus and the coast of Palestine then he wandered over the city of Jerusalem before going to Egypt and the scholars and dignitaries accepted him and honoured him. Andave him food in the courtyard of the Aqsa Mosque, and declared the scholars and dignitaries of the Palestinian cities loyalty to him there, and the Sultan received the keys to the Aqsa Mosque and Dome of the Rock, and expressed joy to enter the prayer, qibla in his possession, and gave the city's dignitaries gifts, and waived tax. $\left({ }^{1}\right)$

\footnotetext{
${ }^{1}$ Mahsna M., Reality of Jerusalem, Amant Amman Alkubra, Amman.P.235 (2004).
}

International Journal of Humanities Social Sciences and Education (IJHSSE) 
The Ottoman rule continued at Jerusalem since that time until they occupied by the British forces on 3 / 9 December 1917. During the four centuries Jerusalem passed through three stages:

The first phase: extended from the entry of the Ottomans to Palestine, until the rule of Ibrahim Pasha in 1831 .

The second phase: continued throughout the reign of Ibrahim Pasha, the period of Egyptian rule (1831-1840)

The third phase: which extended from the exit of the Egyptian rule, until the British occupation of Palestine in the late World War I (1917-1840).

\section{Jerusalem in the First Phase of OtToman Rule (1831-1516 )}

Palestine included five brigades (Sanjak) during the Mamluk period, and continued in the Ottoman era, and became affiliated with the state of Damascus (Sham), and was one of the palaces of Palestine, the Sanjak of Jerusalem, which was divided in the sixteenth century to two areas, which Included 184 villages, Hajj and visit Jerusalem and Hebron as an incentive to intensify administrative centers and security points in Palestine; to ensure the safety of passengers from raids Arabs. $\left({ }^{2}\right)$

in the era of Sultan Sulaiman al-Qanuni, Jerusalem received a great deal of attention. He renovated the Dome of the Rock by replacing the mosaics on the walls of the dome with al-Qashqani, installing most of the marble covering the outer walls from the bottom, renovating the windows and doors, and the dome of the chain in Al-Qashani. The Wall of Jerusalem built between 947-934 AH / 1540-1527 D, in the era of Sultan Sulaiman al-Qanuni, Jerusalem received a great deal of attention. He renovated the Dome of the Rock by replacing the mosaics on the walls of the dome with al-Qashqani, installing most of the marble covering the outer walls from the bottom, renovating the windows and doors, and the dome of the chain in Al-Qashani. The Wall of Jerusalem built between (947-934 AH) / (1540$1527 \mathrm{D}$ ),to protect the city from external aggression and raids by the Bedouins, and prepares the fence of the major and important urban works, the length of about 4 kilometers, the average height of about 12 meters, and has 34 towers. $\left({ }^{3}\right)$, the wall that exists today in the city of Jerusalem.

sulayman alqanuniu restored the castle in 1531 , and the tower built on the right side of the inside of Bab-Khalil in Jerusalem in 1538,he established the Sultan's Pool, the ways of Bab el-Selsela In front of the school of Tnkzip and in the way of the valley , in the courtyard of the camp and near Bab AlNather, Bab al-Asbat in 1536, and the Golden Gate plug, which is one of the doors of Al-Aqsa Mosque, and the opening of the door known as the door (Stanna Mary), , And the mosque was built in 1537 and in his reign. His Russian wife Roxilana in 1552 founded Tekke khasiki Sultan $\left({ }^{4}\right)$, and she founded "alrasasia school" in "harat alwadi" in 1540D $\left({ }^{5}\right)$, Al-Qaimari mosque established, The dome of al' arwah, The dome of alkhudar, Two bathrooms, The tomb of the Prophet David, Minaret of the Castle Mosque, The dome of the Prophet Muhammad, "Ribat biabram jawish ", and "kutab of Babram Gawish".( $\left.{ }^{6}\right)$.Thus clarifying the interest of Sultan Suleiman in the city of Jerusalem, and reconstruction; given the religious status of Muslims.

The Ottoman census, conducted in the late Soliman al-Qawani era in 1563-1562, shows that the population of Jerusalem was as follows: $\left({ }^{7}\right)$

\begin{tabular}{|l|l|l|l|}
\hline \multicolumn{1}{|c|}{ Total } & \multicolumn{1}{c|}{ The Jews } & \multicolumn{1}{c|}{ Christians } & \multicolumn{1}{c|}{ Muslims } \\
\hline 12,617 & 1197 & 1547 & 9873 \\
\hline $100 \%$ & $9,49 \%$ & $12,26 \%$ & $78,25 \%$ \\
\hline
\end{tabular}

It is clear that the vast majority of the inhabitants of Jerusalem were Muslims, then Christians, then Jews, with the vast difference between Muslims, Christians and Jews.

\footnotetext{
${ }^{2}$ Rafiq A., Palestine During The Ottoman Era; Palestinian Encyclopedia, Beirut, pp. 699-701 (n.d.).

${ }^{3}$ Al-Asali K., The Status of Jerusalem in Arab and Islamic History; The Palestinian Encyclopedia, Special Studies Department Beirut, p. 821(1990).

${ }^{4}$ Al-Takiya: A place dedicated to feeding the poor and needy.

${ }^{5}$ Arif A., The History of Jerusalem, Dar Al Ma'arif, Cairo, p. 104 (1991).

${ }^{6}$ Al-Asali K., Op. Cit.,P.822 (1990).

${ }^{7}$ Rafiq M., Op. Cit., p. 738 ( n.d.).
} 
The references point out that during the period between the death of Sultan Suleiman al-Qawani in 1566 and Murad IV in 1622, Jerusalem received no attention, No reconstruction and this is not accurate, Kamel al-Asali reported that there was reconstruction in the Dome of the Rock during the reign of Muhammad III in $1006 \mathrm{AH} / 1597 \mathrm{AD}$, and during the reign of Sultan Ahmad I in $1012 \mathrm{AH} /$ $1603 \mathrm{AD}$, and during the reign of Sultan Mustafa I in $1026 \mathrm{AH} / 1617 \mathrm{AD})\left({ }^{8}\right)$, Which means that Jerusalem received the attention of the Ottoman Empire even in the stage of the sultans weak.

In the era of Murad IV, security broke down, and bandits' attacked convoys and the countryside. The Sultan established a castle named (Castle Murad) at the pools of Solomon, and established inside it a mosque and fifty houses to soldiers' residence to guard the ponds against vandalizing the saboteurs, And in the reign of Sultan Mohammed IV built the minaret inside the castle in 1655, he has established the house of worship next to the path of Shaalan in Al-Quds Holy in 1651. $\left({ }^{9}\right)$.

The famous Ottoman tourist (Olea Chalabi) visited Jerusalem around the year $1670 \mathrm{AD}$, and described and praised it, He noted that there are 2045 shops, 6 great inns, markets and 43 thousand vineyards, in which there are about 1,500 scenes, including an Armenian church, three Roman churches, two Jews churches, 240 house of worship, 7 prayer rooms, 10 Koranic schools, (18) ways, and 70 Tkiyehs, $\left({ }^{10}\right)$ as visited by Hiyari, Nabulsi, Siddiqui, and many Muslim and foreign travellers, praised the city in that era. $\left({ }^{11}\right)$.

It is clear from the above that Jerusalem has undergone a period of recovery and prosperity since the beginning of the Ottoman rule, until the middle of the seventeenth century, at the level of reconstruction, security, religious freedom of the three religions, and in scientific life Commercial traffic, and visiting tourists Muslims and Christians, whom they would not visit, and provide us with a description of their structures and Islamic and Christian sanctuaries if security were not stable.

\section{Revaluation OF NAQIB Al'ASHRAF}

In the late 17th century, the Gaza and Ramle brigades subordinated to the governor of Jerusalem, which draining the population and persecuting them. This led them to revolt, with the increase of Bedouin attacks on the pilgrims, the Sultanate concentrated on the security aspect. The taxes collected from the Jerusalem Municipality and the Gaza Brigade allocated to maintain the security of the Hajj convoy. From imposing taxes and arbitrariness against the people of the region. $\left({ }^{12}\right)$.

The residents of Jerusalem revolted in 1112 AH / 1700 AD when the Sultanate allowed a French Consul to reside in Jerusalem. The scholars considered this a return to the Crusades of their country with a new dress .In front of their protest they cancelled their stay in Jerusalem $\left({ }^{13}\right)$, and the governor of Jerusalem, Kordibram Mohammed Pasha, launched a military campaign at villages and cities, and to impose heavy taxes, and to encroach on the citizens.

So the people of Jerusalem revolted under the leadership of Captain Ashraf, besieged the Jerusalem judge and commander of the military garrison; the governor was removed, and appointed a new governor and reconciliation destinations and the revolution that lasted between 1705 and 1703 ended. $\left({ }^{14}\right)$

During the reign of Sultan Mahmoud, I renewed the construction of the wall of the trench in Jerusalem in 1731D and the construction of the castle mosque $1738 \mathrm{D}$, and then there was sedition in the Church of the Holy Sepulcher in 1757D, between the Greek Orthodox and the Frankish Catholics; the Ottoman Empire and the Orthodox , Assigned to all Christian places in the city, Three years later, Jerusalem - like the rest of the Levant - was hit by a general plague in $1174 \mathrm{AH} / 1760$, which lasted for several months, and caused a great deal of damage $\left({ }^{15}\right)$.

\footnotetext{
${ }^{8}$ Al-Asali K., Op. Cit.,P.822 (1990).

${ }^{9}$ Arif A., Op. Cit.,P.105.(n.d.).

${ }^{10}$ Arif A., Op. Cit.,Pp.105-106.(n.d.).

${ }^{11}$ Rafiq M., Op. Cit., Pp.727-820.( n.d.).

${ }^{12}$ Cohen A., Palestine in the 18th century, the Magnes press, the Hebrew university, Jerusalem. Pp.146-147 (1973)

${ }^{13}$ Sisallam E., and Al-Sinwar Z., The History of Palestine in the Middle Ottoman Period ,

Association of Palestinian Writers and OSWL, Gaza, p. 52(2010)

${ }^{14}$ Manna A., The History of Palestine in the Late Ottoman Period, Palestine Studies Institute, Beirut, pp. 30-36 (1999).

15 Arif A., Op. Cit.,P.106.(1991) ; Mahsna M., Op. Cit., p. 238 (2004).
} 
Those who read the history of Jerusalem can know that the security situation has been disturbed since the beginning of the 18th century. There were disturbances among the Jerusalemites and officials and then the strife between Orthodox Christians and Catholics. Then came the scourge and spread the epidemic, which claimed the lives of large numbers of Jerusalemites, Which means the disruption of the security situation, and the reflection on the scientific, economic, and tourism.

When the movements of the French campaign began from Egypt to Syria led by Napoleon Bonaparte in 1799, the leaders of Jerusalem asked the Ottoman governor of Damascus to supply them with weapons; to defend the city. The governor ordered all the men who were able to take up arms in the Jerusalem Brigade to join the Sultan's army, but Napoleon did not go to Jerusalem. He said Jerusalem didn't mention in the plan it had drawn $\left({ }^{16}\right)$. Napoleon continued to move on the Palestinian coast after committing a terrible massacre in Jaffa. He went to Haifa and Acre and did not send any force towards Jerusalem.

A fire broke out in the Church of the Holy Sepulcher on September 30, 1808, a large part of the western section destroyed, and the fire started on the side of the Armenians. The heads of the Christian communities set up tents in the courtyard of the church to guard them against looting. Muslims took part in the guard, including the Mufti of the Hanafis and naqib al-Ashraf. The Orthodox asked that the Sultan allow them to repair the church. He agreed. The restoration began in May 1809, but the Armenians and Catholics opposed and incited the Muslims. $\left({ }^{17}\right.$ ) (And from that incident shows that the relationship between Muslims and Christians in Jerusalem was strong, to the extent that the Mufti of Jerusalem and naqib al-Ashraf. in the guard of the Church, This is what explains the statement of Father Manuel Muslim in 2017 when Israel decided to stop raising the " adhaan" The call to prayer in Jerusalem. He said: Our churches are open to Muslim brothers to raise the adhaan.

The people of Jerusalem revolted in 1826-1825 against the Ottoman governor because of the high taxes imposed on them and the cruelty in their collection. The families were forced to expel the men of the recipient. A campaign of about 5,000 soldiers was established to force the people to pay taxes. However, The rebels on Jerusalem, and imprisoned dozens of soldiers, They managed themselves by themselves. With the passage of time took the scholars of Jerusalem and its dignitaries estimate the revenge of the governor of Al-sham they send messages to the Sultan and the Wali offers the justification of the revolution and agreed between the parties and ended the revolution, The army returned to Jerusalem in 1826. $\left({ }^{18}\right)$, but the turbulent security situation that reached Jerusalem and the whole of Palestine was more alarming. The harassment of the governor of Egypt, Muhammad Ali, began with the rulers of $\mathrm{Al}$-sham, in order to achieve his ambitions to occupy Al-sham and to annex it to his rule, which is separate from the Ottoman Empire.

\section{JeRUSAlem UnDER EgYPTIAN RULE (1840-1831)}

The forces of Ibrahim Pasha, the son of Muhammad Ali, came from Egypt to Gaza, Jaffa, Haifa, Jerusalem and the Galilee without resistance. The entry into Jerusalem in December 1831 announced by the Egyptians. All taxes and revenues imposed on the Christian and Jewish communities, And their holy places - as Muhammad Ali had promised the European consuls before the campaign came out but that policy provoked scientists and dignitaries Muslims, Anxiety spread in Jerusalem and spread to Mount Nablus. The Muslim dignitaries loyal to the Ottoman Sultan, and recruited the Egyptian campaign of Jerusalem is not large; which led to the strengthening of the army in Jerusalem, and in 1834, a revolution on the Egyptian rule in Palestine and Al-sham, because of the tax imposed on the population, the compulsory recruitment of $10 \%$ of the population, they reached 1500 of the Jerusalem area, because of the collection of arms from the parents to prevent them from resisting the Egyptian policy in the collection of taxes and forced recruitment. . The revolution began in 1834 in Jerusalem, and the rebels attacked the Egyptian army. He went to the castle and rescued by Ibrahim Pasha-The rebels were defeated a number of times, but they tightened their control over the roads leading to Jerusalem to prevent the rescue. Then they intervened after the army exhausted its army and confiscated its ammunition. Ibrahim Pasha left Jerusalem to Jaffa $\left({ }^{19}\right)$.

${ }^{16}$ Ryan M., Jerusalem in the Ottoman Period ; Jerusalem through the Ages, Irbid, p. 247 (2009).

${ }^{17}$ Manna A., Op. Cit.,Pp.111-133 (1999).

${ }^{18}$ Khoury G., The Province of Damascus (1783-1832), p.180 (2001).

${ }^{19}$ Ryan M., Op. Cit.,Pp.249 (2009).

International Journal of Humanities Social Sciences and Education (IJHSSE)

Page $\mid 46$ 
During the reign of the Egyptian government, the windmill established in the west of Jerusalem. It was the first grinding mill in which the Macedonians built their wheat in 1839." alzzawiat Ibrahimia" Place of worship of the mystics built and the citadel built in Wadi al-Jawz and others between Wadi al-Jawz and Mountain al-Tur. The five taxes abolished on agricultural crops. People are planting fruit trees. $\left({ }^{20}\right)$. Nevertheless, the people of Jerusalem rejoiced when Al-sham was returned to Ottoman rule again.

\section{JeRUSALEM Under THE SECOND OTTOMAn RULE (1841-1917)}

During that period, Sultan Abdul Aziz (who is profligate ) repaired and reconstructed the Al-Aqsa Mosque. The road linking Jaffa with Jerusalem established in 1867, and the road connecting Jerusalem with Nablus in 1870 and paved the streets of Jerusalem and its markets in $1863\left({ }^{21}\right)$, During the reign of Sultan Abdul Hamid II, who began his rule in 1876, repairs made in the Dome of the Rock, and the entire Surah (Yassin) written around the octagon of the Dome of the Rock. The rock and the Al-Aqsa Mosque carpeted in 1892, In 1882, Qaytbay's path renewed in the Temple Mount, In the 1980s, the streets of Jerusalem were paved and opened a clinic for free to the public, and in 1888 it decided to build a theatre representing the Arabic, Turkish and French novels, and began to build schools villages, In 1892, a public hospital established in the Sheikh Badr neighbourhood. A public park established in Ras al-Midan. In 1892, a railway established between Jerusalem and Jaffa. A military hospital established in Jerusalem. A fire brigade established. In 1900, The clock tower built, and a road built at the door of Hebron and in 1901, an archaeological museum opened. In 1904, the city's bath repaired. In 1906, Rasheed Bey, the Jerusalem governor, decided to build the Rashidieh school and decided to prevent construction without a permit. $\left({ }^{22}\right)$

World War I broke out in 1914, British forces reached the outskirts of Jerusalem in 1917 and forced to surrender. The extradition document sent by the Jerusalem governor to the British command on $9-8$ December 1917 states that the Ottoman government Decided to withdraw its forces from the city in order to preserve the holy places of desolation. $\left({ }^{23}\right)$

\section{EUROPEAN AND ZIONIST AMBITIONS IN JERUSALEM}

During the Egyptian period, the British established the first European consulate in Jerusalem in 1838. France, Prussia and Sardinia established their consulates in 1843, Austria in 1849, Spain in 1854, The United States in 1857, Russia in 1861, Greece in 1864, and Italy in 1872. $\left({ }^{24}\right)$.

At that stage, the missionary institutions were active. Churches, educational and social services increased in Jerusalem and its environs, and the Jews exploited it, increasing their emigration to Jerusalem, especially from the Netherlands and Germany $\left({ }^{25}\right)$.The European consulates provided protection to the Jews in Jerusalem; Which helped to increase them, In 1849 Montfiori obtained a royal permit allowing the Jews to buy some land. In 1855 he obtained another permit to buy a piece of land outside the city walls. Instead of setting up a hospital as stated in the permit, he established a Jewish residential neighborhood known as his name, The establishment of Jewish neighborhoods, until 1892, eight neighborhoods $\left({ }^{26}\right)$

\section{EXPLORATION AND EXCAVATIONS IN JERUSALEM IN 1867}

When the London Fund Committee announced in 1867 that it was ready to go to Jerusalem to start exploration, drilling and drilling, generous donations came from many internal and external sources. The Queen was the first donor. She donated a personal amount of $£ 150.500$ pounds, and the University of Cambridge the amount of 250 pounds, as other British cities donated Such as Edinburgh and Glasgow, as well as personal donations from a large number of Christian clergymen and British citizens. Over time, the volume of donation and contribution increased, Countries such as Canada,

\footnotetext{
${ }^{20}$ Shaeat S., Al Quds Al Sharif, Cultural Horizons of Jerusalem 74, June 2009, p. 25

${ }^{21}$ Arif A., Op. Cit.,Pp.118-119 (1991).

${ }^{22}$ Al-Asali K., Op. Cit.,Pp.825-826 (1990).

${ }^{23}$ Rusan M., Jerusalem in the Custodian of the Occupation and the British Mandate 1948-1917; Jerusalem through the Ages, Irbid, p. 293 (2009).

${ }^{24}$ Awad A., The Zionist Aspirations in Jerusalem; The Palestinian Encyclopedia, Q2, C6, Beirut, p. 159 (1990).

25 Awad A., Op. Cit., P.841(n.d.)

${ }^{26}$ Abu Bakr A., Jerusalem under Ottoman Rule; History of Jerusalem, Al Quds Open University, Amman , P. $236(2010)$.
} 
Australia, New Zealand and the United States expressed their willingness to contribute financially and put their resources to the service of the Commission and its program. A large number of specialists in the field of archaeology and excavations from Europe and America also announced their readiness to contribute to their personal efforts and to go to Jerusalem for exploration and excavation. $\left({ }^{27}\right)$

The Committee sent its mission to Jerusalem "since a large number of donors to the Fund were referring in particular to matters related to Jerusalem." The directions given to the mission were the need to reach an answer to some of the most controversial issues,

- Locate the so-called anatomical structure

- Determining the year of the Dome of the Rock.

- Determining the location of the Church of the Holy Sepulcher (Is it based on the site of the church established by Emperor Constantine in the fourth century

- Follow the walls of Jerusalem described by the Jewish historian "Josephus" (38 BC - 100 AD)

- Determining the ancient city gates referred to in the Torah.

- Identifying other important places whose real sites are uncertain, such as the city of David and the tomb of Herod $\left({ }^{28}\right)$.

The Commission appointed General Charles Warren (1927-1840) as Head of Mission and dispatched to Jerusalem in 1869 and said to affiliated with the British Military Intelligence. The work of the committee a building block for the fabrication of ancient history of Jews in Palestine. $\left({ }^{29}\right)$

The mission began its work in the area of Al-Aqsa Mosque, where it began to examine the walls, and "Warren" drew a line to prove the closest place to the existence of "Temple Solomon," as he claimed, where he talked about the hardness and durability and splendor of the walls of the mosque. "Warren" digging underground tunnels to find the place of the structure, where he discovered that there are walls below the length of 80-120 feet below the surface of the earth $\left({ }^{30}\right)$.

After his return to London, Warren published several books "Reviving Jerusalem in 1871, and the second book" Al-Quds Al-Difaina in 1876, where he presented a great explanation of his findings and excavations in Jerusalem. $\left({ }^{31}\right)$

The fund went back to Jerusalem to pursue the work begun by Warren. The committee decided to conduct a thorough examination of the remains of the outer wall of the Al-Aqsa Mosque. The Ottoman government gave an excavation permit in 1894, in the area extending from Silwan west to the Qadrun valley in the east. And took over prospecting Plus is assisted by Dickie (Professor of Archeology at the University of Manchester) to do charts and drawings. Excavations conducted by trenches and passages in a manner similar to Warren's. $\left({ }^{32}\right.$ )

"Plus" follows the southern wall of Jerusalem from the Mount of Olives to the Kidron Valley. And locate the towers as you know some of its tower It was part of a complex system of fortifications of great archaeological value, and the Pilsen operations continued until 1897 when the Ottoman permit expired. The Commission published a full description of the excavations in a volume entitled "The Excavations of Jerusalem". $\left({ }^{33}\right)$

Thus, the extent of British interest in prospecting in Jerusalem and to work to confirm the biblical narrative of the Jewish right in Jerusalem, hence the beginning of the phenomenon of biblical archaeologists, who are excavating according to Biblical texts.

\section{Zionist SETTLEMENT In JeRUSALEM DURing OTTOMAn RULE 1858-1917}

The Jews were the smallest community in Jerusalem, after Muslims and Christians, their sources of income limited, most of them handcrafted, and they received donations from European Jews. $\left({ }^{34}\right)$

${ }^{27}$ Jones B., The development of Palestine Exploration, Scribners sons, New York, P.255 (1966)

${ }^{28}$ Qasimia C., Activities of the Palestine Exploration Fund, p. 78. (1980)

${ }^{29}$ Al Jazeera C., Their Archive and History Program, ( 2011)

${ }^{30}$ Jones B., op. cit. P. 266.(n.d.)

${ }^{31}$ www.virtuallibrary.org. Warren, Charles.

${ }^{32}$ Qasimia C., op. cit. P.87(1980)

${ }^{33}$ Qasimia C., op. cit. P.88(1980)

${ }^{34}$ Ben Porat Y., Chapters in the History of Jewish Settlement in Jerusalem, Jerusalem, P.154 (1983).

International Journal of Humanities Social Sciences and Education (IJHSSE)

Page $\mid 48$ 
In 1849, Sir Moses Montefiore visited Jerusalem, resented the situation of the Jews, placed their homes, overcrowded the ghetto, spread poverty and dirt, and decided to help them build a Jewish neighbourhood outside the walls of the city, but the Ottoman authorities did not agree to this $\left({ }^{35}\right)$.

Moshe Montefiore didn't care about the Ottoman rejection and continued his efforts to pressure the Ottoman authorities. In 1854, Montefiore secured \$ 60,000 from one of the wealthy Jews of the United States, who recommended that the amount allocated for the purchase of land in Jerusalem Montefiore able to purchase land outside the walls of the city, in preparation for the first Jewish neighbourhood outside the walls. Montefiore is the first European Jew to own a piece of land in Jerusalem (outside the walls). $\left({ }^{36}\right.$ )

In 1855 , he bought land outside the walls of the old town, located under the Mount of Olives and overlooking the door of "Jaffa" ... He couldn't be allowed to own the land had it not been for the intervention of the British ambassador to the High Court. The land 18,000 square meters, and the foundation stone laid for the construction of the first Jewish settlement known as Kerem Moshe to commemorate the efforts of Montefiore. In 1860, the neighbourhood completed. The new Jew in parity between the Sephardim and the Ashkenazim. $\left({ }^{37}\right)$

Montefiore planned to build a Jewish hospital in Jerusalem, but changed his mind and built a row of charity homes for poor Jewish families. He saw that the Jews had to move from the unhealthy Jewish neighborhood. In 1886 he built the most advanced windmills in Jerusalem, on a hilltop overlooking those houses, so that the Jews would rely on themselves. $\left({ }^{38}\right)$

The idea attracted other Jews. Rabbi "Sallom the Jew" bought a piece of land, known as the "bridge" near the door of Hebron, and bought "Moses Schoen" a piece of land near the door of Hebron. $\left({ }^{39}\right)$

Montefiore's activities and efforts have resonated among the Jews of Europe, who encouraged to come to Jerusalem, where the first Jewish settlement built outside the walls of the Old City. His efforts highly appreciated by the British government, For the development of solutions to the problems of Jews in Europe, through their displacement to Palestine, and the establishment of neighbourhoods and agricultural settlements Zionism $\left({ }^{40}\right)$.

In 1860, some Jewish investors bought some of the new land adjacent to Kerem Moshe and laid the foundation stone for the construction of a new neighbourhood called "Mahane Yisrael" (Israel's Camp). $\left({ }^{41}\right)$. As it increased Move to The rest of the city's neighbourhoods, especially in the vicinity of the "Jewish Quarter" such as Al-Sharaf neighbourhood, Bab Al-Silsilah road, Aqabah Al-Khalidiya, Wadi Al-Wad, either by buying or renting after the lifting of the Ottoman legal barriers, or by the Ottoman Jews, too, and the Jewish expansion of the Christian Quarter was very limited, because the church activity in that neighbourhood was most intense, making access to empty places almost impossible, As there was a Jewish tendency to live among Muslims. Thus the Jewish neighbourhood expanded, but it was never purely Jewish. $\left({ }^{42}\right)$

On the other hand, the Jews targeted the purchase of all the land for sale of land and real estate containing houses, contemporary, and the hangers, mills, Hawakir, vineyards, and farms. It is interesting to note that when the sales cases closed at that stage, it found that most of them targeted the area adjacent to the wall of the Western Al Aqsa Mosque (harat alyhwd, lmagharibat and Ashraf). They also expanded in other routes more like: Bab al-Amoud neighbourhood. This shows that the door became open to the Jews to own all over the city unconditionally, including the following

35 Shafer G., The Relationship between Jews in Exile and Israel, Jerusalem Institute for Israeli Studies, Jerusalem,P..... (2011).

${ }^{36}$ Almadni Ziad., The City of Jerusalem and Its Neighboring in the Late Ottoman Period, 1831-1918, Al Dustour Press, Amman, P.123 (2004).

${ }^{37}$ Asaf M., The Awakening of the Arabs in the Land of Israel and Their Escape, Ministry of Education, Tel Aviv, p.12 (1967).

${ }^{38}$ Annab M., Zionist Settlement in Jerusalem 1967-1993, Beit al-Maqdis Publishing and Distribution, Ramallah,p.46 (2001).

${ }^{39}$ Almadni Ziad., op. cit. P.123(2004).

${ }^{40}$ Encyclopedia Judica: Keter publishing House, Jerusalem ,p.457 ( 1972).

${ }^{41}$ Ben Porat Y., op. cit. P.158 (1983).

${ }^{42}$ Al-Juba, N., The History of Jewish Settlement in the Old City of Jerusalem, Palestine Studies, Beirut, p.104 (2002).

International Journal of Humanities Social Sciences and Education (IJHSSE)

Page | 49 
argument: "Ibrahim ibn Harun Jewish" Jerusalemite Jerusalemite, a citizen of the French consulate purchased from the seller ... All the house ... List Mahalla El Oued "..( $\left.{ }^{43}\right)$

Land purchases in Jerusalem continued, and the establishment of Jewish neighbourhoods. The Mishkenot Shenanim neighbourhood established in 1860 near the Jaffa Gate and the Nahalat Shiva neighbourhood in the same year. Settlement operations continued and in 1878, the fourth neighbourhood in Jerusalem established, "miat shaearaym " meaning "a hundred doors". $\left({ }^{44}\right)$, The founders of that neighbourhood, ("Haredim") are religious, of the immigrants of Russia and Poland. In 1877, the "Even Israel" neighbourhood built and in 1877 the "Beit Ya'akov" (Beit Ya'akov) settlement was established. $\left({ }^{45}\right)$

Active Zionists to solve the problems of the Jews of Yemen in the sanctity A wealthy Jew from Baghdad purchased land in the Silwan area. In 1885, they built twelve houses. In 1890, a neighbourhood built in the Jerusalem suburb known as the "Biot Timen" neighbourhood. $\left({ }^{46}\right)$, in 1981, two new neighbourhoods were established to house the Jews of Yemen: Ezra Israel (Helping Israel) and Neflat Tzvi (Heirs of Zvi). In 1892, there was a significant activity in the establishment of the settlement neighbourhoods in Jerusalem, where several other neighbourhoods built: Beit Ibrahim, opposite the Hebron Gate outside the walls, Damascus, Elazar, Yohale Ya'akov, And a new settlement inaugurated in "Jouraat Al Annab" opposite the door of Hebron, in addition to "Nahlat Ya'aqoub".( $\left.{ }^{47}\right)$

In 1894, Jewish immigrants set up a settlement "Mutsa" on an area of 400 dunums of the land of "Qaluniya" village west of Jerusalem. $\left({ }^{48}\right)$

The construction of the Zionist neighborhoods and the emergence of the Zionist movement as a supporter of the settlement, but at a slower pace, several neighborhoods created: the neighborhood of Nechoul Yaakov outside Jerusalem in front of the door of Hebron, the neighborhood of the house of Minsk, the neighborhood of the house of Joseph America in 1900, and then the neighborhood of Bevin, , And the neighbourhood of the house of Holim in 1903, and the neighbourhood of Zichron Moshe (the memory of Moses) established in the same year, and the safari neighborhood, and the neighborhood of Beit Zirim (house of bouquets of roses) in 1908. $\left({ }^{49}\right)$

Construction continued in the Old City. Several Jewish organizations were able to purchase a large plot of land in the western corner of the Jewish Quarter, with the aim of building residential buildings under the protection of the Austrian consul in Jerusalem. $\left({ }^{50}\right)$, The aim was to penetrate into the city (inside the walls) by purchasing land, housing, renting shops in the commercial markets of the city, controlling commercial and economic movement, and controlling the facilities of life $\left({ }^{51}\right)$, They managed to control the institutions of economic services, from mills, and the presses, oven, a number of wealthy Jews to set up, or purchased in the city, in Jerusalem. The Jews controlled the kerosene trade in the city and became the suppliers of petroleum. $\left({ }^{52}\right)$ This stage of a settlement characterized by the control of individual projects. And was the efforts and efforts made by some enthusiasts of the Jews and others, Where the activities of Montefiore, Rothschild and Alliance France resulted in a significant improvement in the status of the Jews in Jerusalem, which led to an increase in their numbers. Previous efforts were charitable. The apparent goal was to sympathize with the poor Jews and to help them. $\left({ }^{53}\right)$

\section{THE CONCLUSION}

The researcher reached results most important:

\footnotetext{
${ }^{43}$ Ghanem A., Jewish Settlement in Jerusalem, 19th Century, Jerusalem Fifth Conference, Jerusalem International Foundation, Gaza, p.102 (2011).

${ }^{44}$ Al-Modallal W., The Israeli Settlements in Jerusalem . P. 18 ( n.d.)

${ }^{45}$ Abdul Hadi M., The History of Jerusalem, Palest ine Delegation , P.4 (1997).

46 Abdul Hadi M., op. cit., p. 144 (1997).

${ }^{47}$ Salihia M., The City of Jerusalem, Population and Land (Arabs and Jews) 1858-1948, Beirut, P.24 (2009).

${ }^{48}$ Al-Hazmawi M., Land Ownership in Palestine, 1918-1948, Aswar Foundation, Acre, P.72 (1998).

${ }^{49}$ Salihia M., op. cit., p. 24 (2009).

${ }^{50}$ Al-Juba, N., op. cit., p. 105 (2002).

51 Salihia M., op. cit., p. 19 (2009).

${ }^{52}$ Salihia M., op. cit., p. 38 (2009).

${ }^{53}$ Awad A., op. cit., p. 853(1990).
} 
- Jerusalem had a special status in the first Ottoman period, and the Ottoman sultans took care of it, its reconstruction, its development, and the preservation of its Islamic holy sites.

- The Ottoman sultans allowed the Christians the reconstruction of the Church of the Holy Sepulcher, and the Christian holy sites.

- Manifested and clarified the good relations between Muslims and Christians in Jerusalem throughout the Ottoman rule, to the degree of guarding the scholars and dignitaries of the Muslim Church of the Holy Sepulcher when burned.

- Jerusalem didn't develop during the period of Egyptian rule which extended from (1831-1840D).

- Colonial ambitions emerged in Jerusalem, through the establishment of European consulates for a large number of these countries since 1840 .

- Britain, archaeologists and excavations were interested in Jerusalem in the late Ottoman period, with the aim of reaching the Temple of Solomon or proving the right of the Jews in Jerusalem, but none of this achieved.

- Jewish settlement in Jerusalem began with the efforts of Moshe Montefiore then continued, expanded and became in accordance with the plans of the Zionist movement.

- The number of Jews, Jewish neighborhoods in and around Jerusalem in the late Ottoman period increased, and Jews controlled important economic facilities in the city.

\section{AUTHORS' BIOGRAPHY}

Dr Zakaria Ibrahim Hassan Al-Senwar, a Palestinian, born in 1965, In Khan-Younis refugee camp in Gaza Strip, holds a PhD in modern and contemporary history from the Institute of Arab Research and Studies in Cairo in 2006. He became a professor in 2013.He has written 12 books individually or in partnership. He has 25 scholarly research papers, published in scientific journals or scientific conferences. He supervised dozens of scientific theses for referee a master's degree and $\mathrm{PhD}$ in a number of Palestinian and Arab universities. He received the Arab Prize for Heritage, that organized by the Educational Organization (ALECSO) in 2013.

Citation: Dr Zakaria Ibrahim Al-Sinwar. "Jerusalem in the Ottoman Rule (1516-1917 AD)" International Journal of Humanities Social Sciences and Education (IJHSSE), vol 6, no. 1, 2019, pp. 43-51. doi: http://dx.doi.org/10.20431/2349-0381.0601005.

Copyright: () 2019 Authors. This is an open-access article distributed under the terms of the Creative Commons Attribution License, which permits unrestricted use, distribution, and reproduction in any medium, provided the original author and source are credited. 